\title{
PELATIHAN PERMINTAAN DAN PENAWARAN UNTUK SISWA/I PANTI ASUHAN ASIH LESTARI
}

\author{
Yusi Yusianto ${ }^{1}$, Yuniarwati ${ }^{2}$, Tony Sudirgo ${ }^{3}$ \\ ${ }^{1}$ Fakultas Ekonomi, Universitas Tarumanagara \\ Email: yusiy@fe.untar.ac.id \\ ${ }^{2}$ Fakultas Ekonomi, Universitas Tarumanagara \\ Email: yuniarwati@fe.untar.ac.id \\ ${ }^{3}$ Fakultas Ekonomi, Universitas Tarumanagara \\ Email: tonyn@fe.untar.ac.id
}

\begin{abstract}
This community engagement activity aims to provide demand and supply training in economics for students of the Asih Lestari Orphanage, West Jakarta. The provision of this training is to fulfill the demand of the manager of the Asih Lestari Orphanage in an effort to prepare their students for the national exams, especially in Economics. The participants consisted of 10 students, consisting of class IX students, class XI Akt Department (IPS) and Science Department, and class XII-Akt. However, given the time constraints, the training material will focus on the topic of demand and supply. In addition to being given an understanding of the concept of demand and supply also given examples of its application. After that, there are exercises and quizzes to see and assess students' understanding of the material presented. As a result, there was an increase in the scores of all participants between before and after the training, although overall, the results of the training were not satisfactory. Based on all material provided, the material on elasticity is considered the most difficult to understand because it has only been taught. The average value before training is 31.00, while the average value after training is 56.50. After the matter of elasticity is removed, the average value before training is 47.69, while the average value after training is 86.92. If the classification is made according to the class of students, the average grade of XI Science is the highest, which is 92.31. Understanding which is still relatively low on the material, cannot be entirely derived from students. School also determine whether the material provided is in accordance with the curriculum or not. In addition, students do not have supporting references for learning. For this reason, the institution can improve its library facilities so students can learn better.
\end{abstract}

Keywords: economics; Request; offer; training; elasticity learning material.

\begin{abstract}
ABSTRAK
Kegiatan pengabdian pada masyarakat ini bertujuan untuk memberi pelatihan permintaan dan penawaran dalam ilmu ekonomi bagi siswa/i Panti Asuhan Asih Lestari, Jakarta Barat. Pemberian pelatihan ini untuk memenuhi permintaan pengelola Panti Asuhan Asih Lestari dalam upaya menyiapkan siswa-siswanya menghadapi ujian nasional, khususnya dalam mata pelajaran Ekonomi. Peserta terdiri dari 10 siswa/i, yang terdiri dari siswa kelas IX, kelas XI Jurusan Akt (IPS) dan Jurusan Science, dan kelas XII-Akt. Namun, mengingat keterbatasan waktu, materi pelatihan akan memfokuskan pada topik permintaan dan penawaran. Selain diberi pemahaman mengenai konsep permintaan dan penawaran juga diberikan contoh penerapannya. Setelah itu, diberikan latihan dan kuis untuk melihat dan menilai pemahaman siswa atas materi yang disampaikan. Hasilnya, terjadi peningkatan nilai semua peserta antara sebelum pelatihan dan setelah pelatihan, meskipun secara keseluruhan, hasil pelatihan kurang memuaskan. Berdasarkan semua materi yang diberikan, materi mengenai elastisitas dianggap paling sulit dipahami karena baru diajarkan. Nilai rata-rata sebelum latihan adalah 31,00, sedangkan nilai rata-rata setelah pelatihan adalah 56,50. Setelah soal materi elastisitas disingkirkan, maka nilai rata-rata sebelum latihan adalah 47,69, sedangkan nilai rata-rata setelah latihan adalah 86,92. Apabila dibuat klasifikasi menurut kelas siswa, maka nilai rata-rata kelas XI Science adalah yang tertinggi, yakni 92,31. Pemahaman yang masih relatif rendah terhadap materi, tidak dapat sepenuhnya berasal dari siswa/i. Tempat sekolah juga menentukan apakah materi yang diberikan sesuai dengan kurikulum atau tidak. Selain itu, siswa/i tidak memiliki referensi yang menunjang untuk belajar. Untuk itu, pihak panti dapat memperbaiki sarana perpustakaannya agar siswa/i dapat belajar lebih baik.
\end{abstract}

Kata kunci: ilmu ekonomi; permintaan; penawaran; pelatihan; materi pembelajaran elastisitas 


\section{PENDAHULUAN}

Suatu pasar merupakan tempat terjadinya suatu transaksi secara fisik atau virtual. Parkin (2019: 84) mengemukakan bahwa dalam ilmu ekonomi, pasar merupakan berbagai pengaturan yang memungkinkan pembeli dan penjual untuk memperoleh informasi dan melakukan bisnis. Secara garis besar, pasar terdiri dari pasar barang, pasar keuangan, pasar jasa, dan pasar faktor produksi. Dalam kehidupan sehari-hari, suatu transaksi terjadi di pasar apabila harga barang atau jasa yang akan ditransaksikan disepakati oleh kedua pihak, yakni penjual dan pembeli. Penjual mewakili sisi penawaran, sedangkan pembeli mewakili sisi permintaan. Dengan demikian, suatu harga transaksi akan terjadi apabila penawaran bertemu dengan permintaan.

Dalam pemberitaan ekonomi sehari-hari, faktor pemintaan dan penawaran yang mempengaruhi harga pasar sering dijumpai. Sebagai contoh judul berita dari kompas.com mengenai bagaimana cara berpikir permintaan - penawaran digunakan, antara lain:

- "Catat, Garuda Indonesia akan beri diskon harga tiket hingga 70 persen" (Kompas.com $23 / 1 / 2019-10.51)$

- "Impor Jagung 3 kali dalam 3 bulan, Ini Penjelasan Pemerintah" (Kompas.com - 30/1/2019 07.37)

- “Jumlah penumpang Lion Air turun, apa sebabnya?" (Kompas.com - 30/1/2019 - 08.50)

- "Ini Alasan Harga Tiket Pesawat Rute Domestik lebih Mahal dari Internasional" (Kompas.com $-30 / 1 / 2019-09.09$ )

Dalam ilmu ekonomi sederhana, konsep permintaan dan penawaran yang bersifat abstrak tersebut digambarkan dalam bentuk suatu kurva, yakni kurva permintaan dan kurva penawaran. Menurut Maverick (1940), prinsip ekonomi lebih mudah dipahami apabila dipresentasikan dalam bentuk grafik. Selain grafik, ilmu ekonomi juga menggunakan matematika dalam mengekspresikan ide ekonominya. Misalnya, ilmu ekonomi sering menggunakan variabel-variabel yang terukur, yang menunjukkan hubungan antar variabel-variabelnya dalam suatu fungsi.

Di balik kalimat sederhana mengenai kurva permintaan, yakni kurva yang berbentuk dari kiri atas ke kanan bawah, mengandung hukum permintaan. Hukum permintaan (the law of demand) adalah, ceteris paribus, kuantitas barang yang diminta menurun ketika harganya naik. Dengan demikian, kurva permintaan mengandung arti bahwa terdapat hubungan terbalik atau negatif antara harga dan kuantitas yang diminta.

Kurva permintaan di atas dapat ditulis dalam persamaan matematika sebagai berikut:

$$
\mathbf{Q}=\mathbf{a}-\mathbf{b} \mathbf{P}
$$

dengan:

$$
\begin{aligned}
& \mathrm{a}=\text { konstanta } \\
& \mathrm{b}=\text { koefisien } \\
& \mathrm{Q}=\text { kuantitas barang } \\
& \mathrm{P}=\text { harga }
\end{aligned}
$$

Kurva penawaran yang berbentuk dari kiri bawah ke kanan atas, mengandung hukum penawaran. Hukum penawaran (the law of supply) adalah, ceteris paribus, kuantitas barang yang ditawarkan meningkat ketika harganya naik. Dengan demikian, kurva penawaran mengandung arti bahwa terdapat hubungan lurus atau positif antara harga dan kuantitas yang ditawarkan. 
Kurva penawaran di atas dapat ditulis dalam bentuk matematika sebagai berikut:

$$
\mathbf{Q}=\mathbf{c}+\mathbf{d} \mathbf{P}
$$

dengan:

$$
\begin{aligned}
& \mathrm{a}=\text { konstanta } \\
& \mathrm{b}=\text { koefisien } \\
& \mathrm{Q}=\text { kuantitas barang } \\
& \mathrm{P}=\text { harga }
\end{aligned}
$$

Pertemuan antara kurva permintaan dan kurva penawaran akan menghasilkan harga ekuilibrium dan kuantitas ekuilibrium. Ceteris paribus, setiap perubahan harga di luar ekuilibrium akan dikembalikan oleh kekuatan pasar untuk kembali pada keadaan ekuilibriumnya tersebut. Kenaikkan harga di atas harga ekuilibrium, maka terjadi kelebihan penawaran (excess supply). Harga akan turun kembali ke harga ekuilibrium. Di lain sisi, penurunan harga di bawah ekuilibrium akan menimbulkan kelebihan permintaan (excess demand), harga akan naik kembali ke harga ekuilibrium.

Terdapat banyak faktor, baik dari sisi permintaan maupun penawaran, yang mempengaruhi perubahan kuantitas barang yang diminta atau yang ditawarkan. Faktor dari sisi permintaan, antara lain, harga barang tersebut, pendapatan, harga barang substitusi, harga barang komplementer, selera, ekspektasi harga, dan jumlah pembeli (Mankiw, 2018: 69-71). Faktor dari sisi penawaran, antara lain, harga barang tersebut, harga faktor produksi, teknologi, ekspektasi harga, dan jumlah penjual (Mankiw, 2018: 75-76).

Fungsi permintaan di atas dapat ditulis sebagai berikut:

$$
\text { Qd = f (P, Ps, Pc, T, I, Pe, B) }
$$

dengan:

$\mathrm{Qd}=$ kuantitas barang yang diminta

$\mathrm{P}=$ harga barang yang bersangkutan

Ps $=$ harga barang substitusi

Pc = harga barang komplementer

$\mathrm{T}=$ selera

$\mathrm{I}=$ pendapatan

$\mathrm{Pe}=$ ekspektasi harga

$\mathrm{B}=$ jumlah pembeli

Persamaan (3) di atas menunjukkan hubungan antara faktor-faktor yang mempengaruhi jumlah barang yang diminta (antara lain, harga barang tersebut, harga barang substitusi, harga barang komplementer, selera, pendapatan, ekspektasi harga, dan jumlah pembeli) terhadap jumlah barang yang diminta. Dalam persamaan tersebut dinyatakan bahwa hubungan antara harga barang yang bersangkutan dan harga barang komplementer memiliki hubungan negatif terhadap jumlah barang yang diminta; sedangkan harga barang subtitusi, selera, pendapatan, ekspektasi harga dan jumlah pembeli memiliki hubungan positif terhadap jumlah barang yang diminta. 
Fungsi penawaran di atas dapat ditulis sebagai berikut:

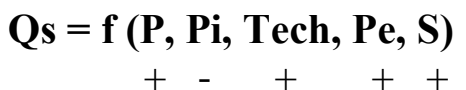

dengan:

Qs = kuantitas barang yang ditawarkan

$\mathrm{P}=$ harga barang yang bersangkutan

$\mathrm{Pi}=$ harga faktor produksi

Tech $=$ teknologi

$\mathrm{Pe}=$ ekspektasi harga

$\mathrm{S}=$ jumlah penjual

Persamaan (4) di atas menunjukkan hubungan antara faktor-faktor yang mempengaruhi jumlah barang yang ditawarkan (antara lain, harga barang tersebut, harga faktor produksi, teknologi, ekspektasi harga, dan jumlah penjual) terhadap jumlah barang yang ditawarkan. Dalam persamaan tersebut dinyatakan bahwa harga faktor produksi memiliki hubungan negatif terhadap jumlah barang yang ditawarkan; sedangkan harga barang tersebut, teknologi, ekspektasi harga, dan jumlah penjual memiliki hubugan positif terhadap jumlah barang yang ditawarkan.

Dalam keadaan ceteris paribus, apabila yang berubah hanya harga barang tersebut, maka pergerakan titik kedudukan hanya berkisar pada area sepanjang kurva permintaan atau kurva penawaran saja, sebagaimana hukum permintaan dan hukum penawaran. Pada kurva permintaan, kenaikkan harga barang tersebut akan menurunkan jumlah barang yang diminta atau penurunan harga barang tersebu akan menaikkan jumlah barang yang diminta. Di sisi lain, pada kurva penawaran, kenaikkan harga barang tersebut akan menaikkan jumlah barang yang ditawarkan atau penurunan harga barang tersebut akan menurunkan jumlah barang yang ditawarkan.

Apabila terjadi perubahan pada faktor diluar harga barang tersebut, maka perubahan faktor tersebut, ceteris paribus, akan merubah permintaan atau penawaran barang tersebut. Hal tersebut ditunjukkan dengan terjadi pergeseran pada kurva permintaan atau penawaran. Sebagai contoh, kenaikkan pendapatan seseorang akan meningkatkan permintaan barang tersebut, yang ditunjukkan dengan pergeseran kurva permintaan ke kanan. Konsekuensinya, harga dan kuantitas barang tersebut yang diminta akan meningkat. Dari sisi penawaran, kenaikkan harga tenaga kerja (faktor produksi), ceteris paribus, akan menurunkan jumlah barang yang ditawarkan. Hal tersebut ditunjukkan dengan kurva penawaran yang bergeser ke kiri.

Di balik bentuk kemiringan (slope) kurva permintaan dan kurva penawaran, di dalamnya mengandung konsep elastisitas. Elastisitas harga permintaan (price elasticity of demand) menunjukkan tingkat responsif jumlah barang yang diminta terhadap perubahan harga. Elastisitas harga penawaran (price elasticity of supply) menunjukkan tingkat responsif jumlah barang yang ditawarkan terhadap perubahan harga. Sesuai dengan hubungan harga dan jumlah barang yang diminta atau yang ditawarkan, maka elastisitas harga permintaan memiliki tanda negatif, sedangkan elastisitas harga penawaran memiliki tanda positif. Jadi, tanda positif dan negatif tersebut hanya menunjukkan hubungan harga dan jumlah barang. Ada pun tingkat elastisitas, terlepas dari tandanya, terbagi menurut 5 klasifikasi, yakni: elastis (elastisitas $>1$ ), inelastic (elastisitas $<1)$, unitary elasticity (elastisitas $=1$ ), elastis sempurna (elastisitas $=\infty$ ) dan inelastis sempurna (elastisitas $=0$ ). 
Rumus elastisitas adalah sebagai berikut (Mankiw, 2018: 92):

$$
\varepsilon=\frac{\Delta Q}{\Delta P} \times \frac{\bar{P}}{\bar{Q}}
$$

Pemahaman konsep permintaan dan penawaran sangat membantu dalam memahami berbagai pasar karena cara berpikirnya sama, yakni menghubungkan harga dan jumlah atau kuantitas. Misalnya, pasar barang yang menghubungkan harga barang dan jumlah barang; pasar valuta asing yang menghubungkan kurs dan jumlah valuta asing; pasar uang yang menghubungkan tingkat bunga dan jumlah uang yang beredar; pasar tenaga kerja yang menhubungkan tingkat upah dan jumlah tenaga kerja; dan sebagainya. Lebih jauh, konsep permintaan dan penawaran juga dapat dimanfaatkan untuk menjelaskan kasus, seperti, inflasi, deflasi, depresiasi mata uang, apreasiasi mata uang, kenaikkan tingkat bunga, penurunan tingkat bunga, kenaikkan tarif impor, dan sebagainya.

\section{METODE PELAKSANAAN PKM}

Metode pelaksanaan pelatihan ini secara umum adalah memberikan ceramah, diskusi, latihan dan kuis. Isi ceramah mencakup, antara lain:

1. Pengertian Permintaan dan Penawaran

2. Faktor-faktor yang Mempengaruhi Permintaan dan Penawaran

3. Kurva Permintaan dan Kurva Penawaran

4. Elastisitas permintaan dan elastisitas penawaran

5. Harga Ekuilibrium

6. Pergerakan Kurva Permintaan dan Kurva Penawaran

7. Kasus yang berhubungan dengan interaksi Permintaan dan Penawaran

Setelah ceramah, diberikan sesi diskusi. Dalam diskusi ini siswa diberi kesempatan untuk mengajukan pertanyaan sehubungan dengan isi materi yang disampaikan sebelumnya. Setelah sesi diskusi, diberikan latihan. Latihan diberikan dalam bentuk gambar dan perhitungan yang berhubungan dengan permintaan dan penawaran. Untuk memastikan pemahaman siswa atas materi yang disampaikan, maka diberikan kuis. Dari hasil kuis ini, tim akan dapat mengevaluasi pemahaman siswa.

Untuk melihat respons peserta terhadap pelaksanaan pengabdian masyakat di Panti Asuhan Asih Lestari, tim memberikan kuesioner kepada para peserta. Dari hasil kuesioner, tim dapat memperoleh masukan dari peserta sebagai bahan evaluasi dan perbaikan pelaksanaan pengabdian masyarakat di masa yang akan datang. Berdasarkan uraian di atas, maka proses pelaksanaan kegiatan pengabdian pada masyarakat di Panti Asuhan Asih Lestari dapat digambarkan seperti pada Gambar 1.

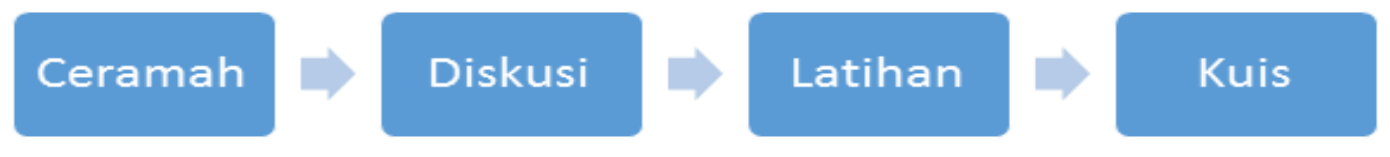

Gambar 1. Proses Pelaksanaan Kegiatan 
Berdasarkan proses pelaksanaan kegiatan di atas, maka susunan jadwal kegiatannya adalah sebagai berkut:

\begin{tabular}{|c|l|c|}
\hline No & \multicolumn{1}{|c|}{ Kegiatan } & Pukul \\
\hline 1 & Registrasi peserta & $07.45-08.00$ \\
\hline 2 & Pengenalan Tim PkM & $08.00-08.15$ \\
\hline 3 & Penyampaian materi & $08.15-11.15$ \\
\hline 4 & Latihan Permintaan dan Penawaran & $11.15-11.45$ \\
\hline 5 & Kuis Permintaan dan Penawaran & $11.45-12.15$ \\
\hline 6 & Pembahasan Kuis & $12.15-12.30$ \\
\hline 7 & Ramah tamah dengan peserta & $12.30-13.00$ \\
\hline
\end{tabular}

\section{HASIL DAN PEMBAHASAN}

Pada pelatihan ini siswa/i diberikan pemahaman dari mulai konsep atau hukum permintaan dan penawaran, bentuk kurvanya, latar belakang bentuk kurvanya yang ditunjukkan melalui pendekatan matematika sederhana, perbedaan istilah movement (pergerakan) dan shift (pergeseran) dalam kurva permintaan dan kurva penawaran, konsep elastisitas pada kurva permintaan dan penawaran, kondisi ekuilibrium hasil dari interaksi permintaan dan penawaran, dan perubahan kondisi ekuilibrium di pasar. Tabel 1 menunjukkan hasil penilaian siswa/i sebelum dan setelah mengikut pelatihan.

Tabel 1. Hasil Nilai Sebelum (Pre) dan Setelah (Post) Latihan

\begin{tabular}{|l|c|c|c|}
\hline \multicolumn{1}{|c|}{ Nama } & Kelas & Pre & Post \\
\hline Alfredo Amos (XII-Akt) & $12 \mathrm{Akt}$ & 35 & 45 \\
\hline Fiani (XI - Akt) & $11 \mathrm{Akt}$ & 25 & 65 \\
\hline Mega R. (XI - IPS) & $11 \mathrm{IPS}$ & 45 & 60 \\
\hline Caroline Helen E. (XII-Akt) & $12 \mathrm{Akt}$ & 40 & 65 \\
\hline Federico Pefer (XI-Science) & $11 \mathrm{IPA}$ & 35 & 65 \\
\hline Wina P. Agustin (IX) & 9 & 0 & 45 \\
\hline Dana Destriyanti (XII-Akt) & $12 \mathrm{Akt}$ & 40 & 70 \\
\hline Yonathan (XI-IPS) & $11 \mathrm{IPS}$ & 30 & 50 \\
\hline Lisa Charisa (XI-Science) & $11 \mathrm{IPA}$ & 30 & 55 \\
\hline Rasel Wulandari (XI-Akt) & $11 \mathrm{Akt}$ & 30 & 45 \\
\hline
\end{tabular}

Tabel 1 menggambarkan bahwa semua peserta memiliki nilai di bawah 50 sebelum mengikuti pelatihan. Setelah diberikan pelatihan, 50 persen nilai peserta di atas 60 . Beberapa catatan yang dapat diperoleh dari hasil tabel 1:

- Peserta kelas IX belum pernah mendapat materi pelatihan ini di sekolah. Makanya, jawabannya salah semua sebelum pelatihan. Namun, setelah mengikuti pelatihan, angkanya menjadi 45. Angka yang termasuk lumayan bagi peserta yang baru diperkenalkan materi ini dalam waktu singkat.

- Peserta jurusan Science, ternyata memiliki kenaikan nilai yang relatif besar setelah mengikuti pelatihan. Hal ini menunjukkan kemampuan memahami yang baik bagi peserta yang bukan konsentrasinya.

- Dari empat peserta kelas XI - Akt (IPS), dua peserta memiliki nilai 60 dan ke atas. Dua peserta mendapat nilai di bawah 60.

- Dari tiga peserta kelas XII Akt (IPS), dua peserta memiliki nilai di atas 60. Satu peserta masih lemah dalam memahami materi yang diajarkan.

- Dari tujuh peserta Jurusan Akt (IPS), empat peserta memiliki nilai di atas 60. 
- Nilai tertinggi setelah pelatihan diperoleh Dana Destriyanti (kelas XII Akt)..

Secara keseluruhan, harus diakui, hasil pelatihan kurang memuaskan. Nilai rata-rata sebelum pelatihan adalah 31,00 , sedangkan nilai rata-rata setelah pelatihan adalah 56,50. Namun, menariknya, setelah pelatihan, nilai rata-rata jurusan IPA atau Science $(60,00)$ lebih tinggi daripada nilai rata-rata jurusan IPS atau Akuntansi $(57,14)$.

Pada dasarnya semua materi pelatihan diajarkan di bangku sekolah, sebagaimana terlihat pada kurikulum SMA Jurusan IPS. Masalahnya, materi tersebut diajarkan secara terpisah bukan dalam suatu kerangka berpikir sehingga siswa/i tidak melihat materi permintaan dan penawaran sebagai suatu konsep berpikir mengenai kondisi pasar, melainkan hanya melihatnya sebagai materi parsial tanpa mengetahui manfaatnya dalam mengevaluasi kondisi pasar.

Kesan tersebut muncul ketika siswa/i SMA Jurusan IPS ditanya mengenai materi tersebut. Hampir semuanya mengatakan pernah diajar materi yang diberikan, kecuali materi elastisitas. Namun, ketika ditanya mengenai manfaat memahami materi konsep permintaan dan penawaran, siswa/i tidak dapat menjelaskannya. Tabel 2 merupakan hasil angket dari peserta mengenai materi yang diperoleh dari sekolah.

Tabel 2. Materi Pelajaran Ekonomi yang diperoleh di Sekolah

\begin{tabular}{|c|c|c|c|c|c|c|c|c|}
\hline \multirow{3}{*}{ Nama (Kelas) } & \multicolumn{8}{|c|}{ Peserta sudah belajar di sekolah materi tentang: } \\
\hline & \multicolumn{2}{|c|}{$\begin{array}{c}\text { Hukum } \\
\text { Permintaan dan } \\
\text { Penawaran }\end{array}$} & \multicolumn{2}{|c|}{$\begin{array}{c}\text { Kurva } \\
\text { Permintaan dan } \\
\text { Penawaran }\end{array}$} & \multicolumn{2}{|c|}{$\begin{array}{l}\text { Ekuilibrium di } \\
\text { pasar }\end{array}$} & \multicolumn{2}{|c|}{ Elastisitas } \\
\hline & Sudah & Belum & Sudah & Belum & Sudah & Belum & Sudah & Belum \\
\hline Alfredo Amos (XII-Akt) & 1 & & 1 & & & 1 & & 1 \\
\hline Fiani (XI - Akt) & 1 & & 1 & & 1 & & & 1 \\
\hline Mega R. (XI - IPS) & 1 & & 1 & & & 1 & 1 & \\
\hline Caroline Helen E. (XII-Akt) & 1 & & 1 & & 1 & & & 1 \\
\hline Federico Pefer (XI-Science) & 1 & & 1 & & 1 & & & 1 \\
\hline Wina P. Agustin (IX) & 1 & & & 1 & & 1 & & 1 \\
\hline Dana Destriyanti (XII-Akt) & 1 & & 1 & & 1 & & & 1 \\
\hline Yonathan (XI-IPS) & 1 & & 1 & & & 1 & & 1 \\
\hline Lisa Charisa (XI-Science) & 1 & & 1 & & 1 & & & 1 \\
\hline Rasel Wulandari (XI-Akt) & 1 & & 1 & & 1 & & & 1 \\
\hline Total & 10 & - & 9 & 1 & 6 & 4 & 1 & 9 \\
\hline
\end{tabular}

Tabel 2 di atas menunjukkan bahwa meskipun sebagian besar pernah memperoleh materi mengenai hukum permintaan \& hukum penawaran, dan Kurva permintaan \& kurva penawaran. Namun, belum semua mempelajari materi mengenai ekuilibrium pasar. Bahkan, materi elastisitas sangat jarang diberikan di sekolah. Hampir semua peserta menyatakan materi tersebut baru dipelajari dan masih sulit memahaminya.

Masalah lainnya adalah peserta tidak mengetahui buku teks Ekonomi yang digunakan di sekolahnya. Berdasarkan informasi tersebut maka dapat dipahami apabila pemahaman siswa/i, khususnya Jurusan Akt (IPS) masih relatif rendah. Berdasarkan pertimbangan di atas, maka jawaban siswa/i dievaluasi. Ternyata, sebagaimana jawaban siswa/i pada angket bahwa mereka belum mendapat material mengenai elastisitas di sekolah, soal elastisitas tidak dapat dijawab dengan benar. Setelah soal elastisitas dihilangkan, total soal latihan yang sebelumnya adalah 20 , 
sekarang totalnya menjadi 13 . Tabel 3 menggambarkan nilai siswa/i setelah soal elastisitas disingkirkan.

Tabel 3. Nilai Sebelum (Pre) dan Setelah (Post) Latihan Soal di Luar Elastisitas

\begin{tabular}{|l|c|c|r|}
\hline \multicolumn{1}{|c|}{ Nama } & Kelas & \multicolumn{1}{c|}{ Pre } & \multicolumn{1}{c|}{ Post } \\
\hline Alfredo Amos (XII-Akt) & $12 \mathrm{Akt}$ & 53.85 & 69.23 \\
\hline Fiani (XI - Akt) & $11 \mathrm{Akt}$ & 38.46 & 100.00 \\
\hline Mega R. (XI - IPS) & 11 IPS & 69.23 & 92.31 \\
\hline Caroline Helen E. (XII-Akt) & $12 \mathrm{Akt}$ & 61.54 & 100.00 \\
\hline Federico Pefer (XI-Science) & 11 IPA & 53.85 & 100.00 \\
\hline Wina P. Agustin (IX) & 9 & - & 69.23 \\
\hline Dana Destriyanti (XII-Akt) & $12 \mathrm{Akt}$ & 61.54 & 100.00 \\
\hline Yonathan (XI-IPS) & 11 IPS & 46.15 & 76.92 \\
\hline Lisa Charisa (XI-Science) & 11 IPA & 46.15 & 84.62 \\
\hline Rasel Wulandari (XI-Akt) & $11 \mathrm{Akt}$ & 46.15 & 69.23 \\
\hline
\end{tabular}

Apabila siswa/i tersebut dikelompokkan menurut kelasnya, Tabel 4 menunjukkan perbandingan rata-rata nilai kelas antara sebelum dan setelah latihan pada dua jenis soal. Soal - 1 adalah seluruh soal yang diajukan, sedangkan soal-2 adalah soal yang menghilangkan materi soal tentang elastisitas. Nilai soal-1 ditunjukkan oleh nilai-1, sedangkan nilai soal-2 ditunjukkan oleh nilai-2.

Tabel 4. Nilai Rata-rata Sebelum dan Setelah Latihan pada Soal-1 dan Soal-2

\begin{tabular}{|l|c|c|c|c|}
\hline \multirow{2}{*}{ Kelompok Kelas } & \multicolumn{2}{c|}{ Nilai - 1 } & \multicolumn{2}{c|}{ Nilai - 2 } \\
\cline { 2 - 5 } & \multicolumn{1}{c|}{ Pre } & \multicolumn{1}{c|}{ Post } & \multicolumn{1}{c|}{ Pre } & \multicolumn{1}{c|}{ Post } \\
\hline Kelas IX & - & 45.00 & - & 69.23 \\
\hline Kelas XI (Akt dan IPS) & 32.50 & 55.00 & 50.00 & 84.62 \\
\hline Kelas XI (Science) & 32.50 & 60.00 & 50.00 & 92.31 \\
\hline Kelas XII (Akt) & 38.33 & 60.00 & 58.97 & 89.74 \\
\hline Total & $\mathbf{3 1 . 0 0}$ & $\mathbf{5 6 . 5 0}$ & $\mathbf{4 7 . 6 9}$ & $\mathbf{8 6 . 9 2}$ \\
\hline
\end{tabular}

Tabel 4 menunjukkan bahwa, sebagaimana ditunjukkan oleh data individu pada tabel 1 dan tabel 3, baik nilai-1 maupun nilai-2 menunjukkan bahwa nilai setelah latihan lebih tinggi daripada sebelum latihan. Apabila rata-rata total nilai-1 setelah latihan adalah 56,50, maka setelah menyisihkan materi soal elastisitas rata-rata total nilai-2 setelah latihan adalah 86,92 . Selain itu, tabel 4 juga menunjukkan bahwa siswa kelas XI Science memiliki nilai rata-rata tertinggi.

\section{KESIMPULAN DAN SARAN}

Kegiatan pengabdian kepada masyarakat telah dilaksanakan pada hari Sabtu, tanggal 23 Maret 2019. Peserta terdiri dari 10 siswa/i, yang terdiri dari siswa kelas IX, kelas XI Jurusan Akt (IPS) dan Jurusan Science, dan kelas XII-Akt. Pelaksanaan kegiatan berlangsung lancar dan tertib. Peserta cenderung pasif, namun mau menjawab ketika ditanya.

Secara keseluruhan, hasil pelatihan kurang memuaskan. Nilai rata-rata sebelum latihan adalah 31,00 , sedangkan nilai rata-rata setelah pelatihan adalah 56,50. Namun, menariknya, setelah 
pelarihan, nilai rata-rata jurusan IPA atau Science $(60,00)$ lebih tinggi daripada nilai rata-rata jurusan IPS atau Akuntansi $(57,14)$. Dari semua materi yang diberikan, materi mengenai elastisitas dianggap paling sulit dipahami karena baru diperoleh.

Setelah soal materi elastisitas disingkirkan, maka nilai rata-rata sebelum latihan adalah 47,69, sedangkan nilai rata-rata setelah latihan adalah 86,92. Apabila dibuat klasifikasi menurut kelas siswa, maka nilai rata-rata kelas XI Science adalah yang tertinggi, yakni 92,31.

Pemahaman yang masih relatif rendah terhadap materi, tidak dapat sepenuhnya berasal dari siswa/i. Tempat sekolah juga menentukan apakah materi yang diberikan sesuai dengan kurikulum atau tidak. Selain itu, siswa/i tidak memiliki referensi yang menunjang untuk belajar. Untuk itu, pihak panti dapat memperbaiki sarana perpustakaannya agar siswa/i dapat belajar lebih baik.

\section{Ucapan Terima Kasih}

Terima kasih disampaikan kepada Lembaga Penelitian dan Pengabdian kepada Masyarakat (LPPM) Universitas Tarumanagara, yang telah memberikan pendanaan, sehingga terselengaranya PKM ini. Kepada rekan-rekan tim dan para mahasiswa terimakasih juga atas kerjasama dan bantuannya.

\section{REFERENSI}

Mankiw, N. Gregory (2018). Principles of Economics. $8^{\text {th }}$ edition. Singapore: Cengage.

Maverick, Lewis A.,(1940). "Demand and Supply Curve". The Quarterly Journal of Economics. February. 54(2): 307-313.

Parkin, Michael, (2019). Economics. $13^{\text {th }}$ edition. Harlow: Pearson

"Catat, Garuda Indonesia akan beri diskon harga tiket hingga 70 persen" (Kompas.com $23 / 1 / 2019-10.51)$

"Impor Jagung 3 kali dalam 3 bulan, Ini Penjelasan Pemerintah" (Kompas.com - 30/1/2019 07.37)

"Jumlah penumpang Lion Air turun, apa sebabnya?" (Kompas.com - 30/1/2019 - 08.50)

"Ini Alasan Harga Tiket Pesawat Rute Domestik lebih Mahal dari Internasional" (Kompas.com 30/1/2019-09.09) 